\title{
ANALISIS GAYA BELAJAR SISWA BERPRESTASI
}

\author{
Raden Dhea Fitrilia ${ }^{\text {a) }}$, Ratih Purnamasari $2^{\left.a^{*}\right)}$, Yuyus Rustandi a) \\ a) Universitas Pakuan, Kota.Bogor, Indoensia........ \\ *)e-mail korespondensi: ratihpurnamasari@unpak.ac.id
}

\author{
Riwayat Artikel \\ diterima 26 November 2021 \\ direvisi 15 Desember 2021 \\ disetujui 30 Desember 2021
}

\begin{abstract}
Abstrak.
Analisis Gaya Belajar Siswa Berprestasi. Bertujuan untuk mengidentifikasi gaya belajar dominan yang dimiliki seorang siswa berprestasi di SDN Semeru 1 Kota Bogor serta faktor apa saja yang mempengaruhi prestasi siswa tersebut. Jenis penelitian yakni kualitatif dengan metode studi kasus. Teknik pengumpuan data dilakukan dengan wawancara, observasi, serta dokumentasi. Hasil penelitian menunjukkan bahwa siswa tidak terlalu reaktif terhadap suara, mudah fokus, lebih cepat memahami informasi baru dengan melihatnya, mampu duduk tenang selama mengikuti pembelajaran, menjawab pertanyan lisan secara singkat langsung pada intinya serta menyukai kegiatan belajar dengan cara membaca sehingga dapat disimpulkan gaya belajar dominan yang dimiliki subjek yakni gaya belajar visual. Sementara faktor yang mempengaruhi prestasi subjek yakni adanya minat dan motivasi belajar yang tinggi, memiliki sikap pantang menyerah dan ulet serta adanya dukungan dari guru dan orang tua subjek.
\end{abstract}

Kata Kunci: Gaya Belajar; Prestasi Belajar

\section{OUTSTANDING STUDENTS' LEARNING STYLE ANALYSIS}

\begin{abstract}
Analysis of Achievement Student Learning Styles. The aim is to identify the dominant learning style of an outstanding student at SDN Semeru 1 Bogor City and what factors influence the student's achievement. The type of research is qualitative with the case study method. The technique of collecting data is done by interview, observation, and documentation. The results showed that students were not too reactive to sound, easily focused, understood new information more quickly by looking at it, were able to sit quietly during learning, answered short oral questions to the point, and liked learning activities by reading so that it could be concluded that the dominant learning style was that the subject has is a visual learning style. While the factors that affect the subject's achievement are the high interest and motivation to learn, having an unyielding and tenacious attitude, and the support from the subject's teachers and parents.
\end{abstract}

Keywords: Learning Style; Learning Achievement

\section{PENDAHULUAN}

Guru sebagai tenaga pendidik harus mampu membantu siswa dalam mencapai tujuan pembelajaran. Tercapainya tujuan tersebut akan memberikan semangat bagi siswa untuk terus belajar serta mempermudah tercapainya tujuan belajar pada tahap selanjutnya.Apabila siswa mampu mencapai keseluruhan tujuan pembelajaran dapat dikatakan bahwa siswa tersebut berhasil dalam belajar. Namun, pada kenyataanya tidak semua siswa mampu mencapai tujuan pembelajaran yang ditetapkan. Hal ini karena setiap siswa memiliki daya tangkap berbeda. Faktor internal lainnya yang mempengruhi keberhasilan siswa mencapai tujuan pembelajaran diantaranya kesehatan siswa, minat dan motivasi, serta cara belajar siswa. Sedangkan faktor eksternal atau faktor yang besal dari luar meliputi keluarga, sekolah, masyarakat, serta lingkungan sekitar.

Dari bebagai faktor tersebut gaya belajar merupakan hal yang masih kurang diperhatikan baik oleh guru maupun siswa. Gaya belajar sendiri memiliki pengertian cara termudah dan tercepat bagi siswa untuk memahami, menyerap, dan mengolah informasi yang didapatkannya sehingga informasi tersebut dapat tersimpan lama dalam memori. Perbedaan gaya belajar tersebut harus dijadikan pertimbangan ketika guru merencanakan kegiatan pembelajaran. Tidak hanya penting untuk diketahui guru, siswa juga harus mengetahui gaya belajarnya masing-masing. Pengetahuan siswa akan gaya belajarnya akan membantu mereka menemukan strategi tepat dalam menentukan bagaimana cara belajar termudah dan tercepat bagi mereka. Selain itu siswa juga akan lebih mudah menyesuaikan kenyamanan dalam aktivitas belajar.

Penelitian mengenai gaya belajar telah banyak dilakukan peneliti terdahulu diantaranya penelitian Fitriani Rahmat Nur Azis dkk dengan judul "Analisis Gaya Belajar Visual, Auditorial, dan Kinestetik Siswa Berprestasi di SD Negeri Ajibarang Wetan". Berdasarkan penelitian ketiga siswa berprestasi di SDN Ajibarang Wetan dominan menerapkan gaya belajar visual. Kebiasaan-kebiasaan yang menunjukkan gaya belajar visual pada siswa berprestasi yakni memiliki catatan yang rapi dan teratur. Siswa berprestasi tidak memiliki kesulitan untuk mencatat materi yang diberikan guru. Siswa berprestasi belajar dengan berorientasi pada gambar. Siswa akan mudah mengingat materi melalui asosiasi visual. Selain itu, siswa berprestasi memiliki kemampuan yang kurang dalam melakukan dialog secara langsung. Jadi, siswa berprestasi cenderung tidak menyukai pembelajaran diskusi. Siswa berprestasi juga merupakan siswa yang reaktif terhadap suara.

Berkaitan dengan prestasi, pada kenyataannya setiap siswa sebagai individu unik memiliki potensi kecerdasan 
berbeda sehingga rendahnya nilai yang diperoleh seorang peserta didik tidak dapat dijadilan indikator bahwa yang bersangkutan tidak mampu berprestasi. Ruang lingkup prestasi tidak terbatas pada prestasi akademik saja, karena masih terdapat prestasi non akademik berupa suatu prestasi yang diperoleh dari kegiatan belajar di luar kelas seperti ekstrakulikuer pramuka, voli, futsal, atau pancak silat. Saat melakukan wawancara dengan guru kelas empat, diperoleh informasi bahwa terdapat seorang peserta didik memiliki prestasi akademik tinggi bernama Rafa. Siswa tersebut selalu mendapat peringkat tiga besar sejak kelas 1 SD. Selain berprestasi di bidang akademik siswa tersebut berprestasi juga di bidang non akademik. Kemampuannya dalam permainan olahraga futsal membuatnya terpilih mengikuti SSO Turnamen School Futsal Sekolah Dasar Kota Bogor kemudian berhasil mendapatkan juara II dalam perlombaan tersebut.

Bedasarkan uraian di atas maka peneliti bermaksud mengadakan penelitian dengan judul "Analisis Gaya Belajar Siswa Berprestai" agar tidak terjadi pembahasan yang meluas dan tidak terbatas, maka permasalahan hanya difokuskan pada gaya belajar siswa berprestasi di kelas IV SDN Semeru 1. Perumusan masalah yang akan diangkat dalam penelitian ini adalah :

1. Bagaimana Gaya Belajar Siswa Berprestasi kelas di Sekolah Dasar Negeri Semeru 1 Kota Bogor?"

2. Faktor apa yang mempengaruhi prestasi belajar siswa di SDN Semeru 1 Kota Bogor?"

Setiap siswa memiliki beragam cara untuk memahami, menyerap, dan mengolah informasi yang disebut dengan gaya belajar. Berbagai teori telah mengungkapkan pengertian dari gaya belajar menurut Priyatna (2013:4) gaya belajar adalah cara dimana anak-anak menerima informasi baru dan proses yang akan mereka gunakan untuk belajar. Sebagian anak menerima inforasi lebih baik dengan cara visual, sebagian lagi dengan cara auditori, sementara yang lain mungkin lebih efektif mengambil informasi melalui taktil. Pendapat tersebut sejalan dengan Priansa (2017: 50) yang menjelaskan bahwa gaya belajar siswa merupakan kombinasi dari cara siswa menyerap, mengatur, dan mengolah informasi. Shimatul (2013:30) memberikan istilah yang sama antara gaya belajar dengan tipe belajar menurutnya gaya belajar merupkan bagaimana cara seseorang menyerap informasi, kemudian mengolahnya serta memanifestasikan dalam wujud nyata perilaku hidupnya.

Gaya belajar berkaitan dengan cara siswa menyerap informasi dengan mudah atau sering disebut modalitas serta bagaimana mengolah informasi tersebut. Penelitian akan gaya belajar sebenarnya telah lama dilakukan para ahli antara lain oleh Michael Grinder. Grinder dalam Priansa (2017:43) mengemukakan berbagai gaya belajar siswa yaitu 1) gaya belajar visual merupakan gaya belajar dengan cara melihat, 2) gaya belajar auditorial berasal dari kata audio yang berarti sesuatu yang berhubungan dengan pendengaran. Gaya belajar audio merupakan gaya belajar dengan mendengarkan, 3) Kinestetik Kinestetik berasal dari kata kinetik yang berarti gerak. Gaya belajar kinestetik adalah gaya belajar dengan gaya bergerak, bekerja, dan menyentuh (praktik langsung).
Subini (2013:14) membagi modalitas belajar dalam tiga kelompok yakni 1) visual learning adalah gaya belajar dengan cara melihat sehingga mata memegang peranan penting, 2) auditori Learning yaitu gaya belajar yang dilakukan seseorang untuk memperoleh informasi dengan memanfaatkan indera telinga. Oleh karena itu mereka sangat mengandalkan telinganya untuk mencapai kesuksesan belajar, 3) kinesthetic Learning cara belajar yang dilakukan seseorang untuk memperoleh inforasi dengan melakukan pengalaman, gerakan, dan sentuhan. Hidayat (2012:102) menguraikan jenis-jenis gaya belajar antara lain 1) auditori merupakan cara belajar dengan cara mendengarkan petunjuk lisan atau belajar dengan cara mendengarkan 2) visual merupakan belajar dengan melihat dan mengamati, mengaitkan yang sedang dipelajari dengan sesuatu yang terlihat 3) kinestetik merupakan belajar dengan melibatkan anggota tubuh, apa yang sedang dipelajari diperagakan.

Guru sebagai perencana pembelajaran sebaiknya mengetahui berbagai gaya belajar yang dimiliki siswanya. Gaya belajar yang dimiliki siswa dapat dilihat dari perilaku maupun kebiasaan yang ditunjukkan mereka saat melakukan aktivitas belajar. Suyono dan Hariyanto (2013:151) mendeteksi gaya belajar siswa berdasarkan kebiasaan (habbit) anak ketika belajar antara lain :

\section{A. Visual}

a) lebih mudah mengigat apa yang dilihat daripada yang didengar, b)mudah mengingat dengan asosiasi visual, c) pembaca yang cepat dan teku, memiliki hobi membaca, d) lebih suka membaca sendiri daripada dibacakan, e) biasa berbicara dengan cepat, karena dia tidak merasa perlu mendengarkan esensi pembicaraannya, f) mempunyai masalah untuk merngingat instruksi verbal, kecuali jika dituliskan, dan sering minta bantuan orang lain untuk mengulangi intruksi verbal tersebut, g) sering lupa menyampaikan pesan verbal kepada orang lain, h) pengeja yang baik, kata demi kata, i) sering menjawab pertanyaan dengan jawaban singkat, ya atau tidak, sudah atau belum, j) mempunyai kebiasaan rapi dan teratur, karena itu yang akan dilihat orang, k) mementingkan penampilan, baik dalam hal pakaian maupun presentasi, 1) memiliki kemampuan dalam perencanaan dan pengaturan jangkan panjang yang baik, m) teliti terhadap rincian, hal-hal kecil yang harus dilakukan, n) biasanya tidak terganggu oleh suara ribut, o) Lebih suka melakukan demonstrasi daripada berpidato, p) membutuhkan pandangan dan tujuan yang menyeluruh dan bersikap waspada sebelum secara mental merasa pasti tenang suatu masalah atau proyek, terbiasa melakukan check and recheck sebelum membuat simpulan, q) lebih menyukai seni visual daripada seni musik, r) suka mencorat coret tanpa arti sebelum berbicara di telepon atau pada saat melakukan rapat.

\section{B. Audio}

a) belajar dengan mendengarkan dan mengingat apa yang didiskusikan daripada apa yang dilihatnya, b) berbicara kepada diri sendiri saat belajar dan bekerja, c) senang membaca dengan keras dan mendengarkannya, c) berbicara dengan irama berpola, d) biasanya menjadi pembicara yang fasih, e) menggerakkan bibir dan mengucapkan tulisan di 
buku saat membaca, f) suka berbicara, suka berdiskusi, dan menjelaskan sesuatu dengan panjang lebar, g) lebih pandai mengeja dengan keras daripada menuliskannya, h) merasa kesulitan dalam menulis tetapi hebat dalam bercerita, i) dapat mengulangi kembali dan menirukan nada, birama, dan warna suara, j) mudah terganggu oleh keributan, ia akan sukar berkonsentrasi, k) mempunyai masalah dengan pekerjaan yang melibatkan visualisasi, l) lebih suka gurauan lisan daripada membaca komik, m) lebih menyukai musik daripada seni lukis atau seni dengan hasil tiga dimensi.

\section{Kinestetik}

a) selalu berorientasi pada fisik dan banyak gerak, b) banyak menggunakan isyarat tubuh., c) menggunakan jari sebagai petunjuk tatkala membaca, d)menghafal dengan cara berjalan dan melihat, e) otot-otot besarnya berkembang, f) menanggapi perhatian fisik, g) tidak dapat duduk diam dalam waktu lama, h) menyentuh orang lain untuk mendapatkan perhatian mereka, i) menggunakan kata-kata yang menggandung aksi, j) ingin melakukan segala sesuatu, k) berdiri dekat ketika berbicara dengan orang lain, l) berbicara dengan perlahan, $\mathrm{m}$ ) suka belajar memanipulasi (mengembangkan data atau fakta) dan praktik, n) tidak dapat mengingat letak geografi, kecuali jika ia pernah datang ke tempatt tersebut, o) menyukai buku-buku yang berorientasi pada plot, mencerminkan aksi dengan gerakan tubuh saat membaca sebagai manifestasi penghayatan terhadap apa yang dibaca, p) Kemungkinan memiliki tulisan yang jelek, q) menyukai permainan yang membuat sibuk.

Kegiatan pembelajaran yang dirancang dengan memperhatikan gaya belajar siswa akan membuat mereka nyaman saat belajar dan suasana kelas menjadi kondusif Priyatna (2013:24) memaparkan perencanaan pembelajaran yang dapat mengakomodasi gaya belajar siswa diantaranya :

\section{A. Pembelajar Visual}

a) tampilkan ide-ide secara visual di papan tulis atau pada OHP atau Infocus, ajarkan siswa untuk memvisualisasikan kata-kata ejaan, soal-soal matematika, dan lain-lain, b) memasukkan latihan spasial, membayangkan citra, bahan bacaan yang kaya fantasi, dan aktivitas-aktivitas visualisasi lainnya ke dalam kurikulum, c) hindari sistem drill, pengulangan, dan hafalan, d) mengizinkan siswa untuk menggunakan komputer untuk pengerjaan tugas-tuga, e) berikan tes tanpa batas waktu, g) penilaian atas tugas makalah harus lebih condong kepada isi jawaban bukan pada format jawaban, h) untuk siswa yang cerdas tetapi nampak bersusah payah dengan tugas-tugas yang mudah dan sekuensial, maka kita dapat memberinya tugas yang lebih canggih dan lebih kompleks, h) menunjukkan model peran orang dewasa yang sukses yang dulunya termasuk pembelajar visual spasial. Tetap mendukung secara emosional.

\section{B. Pembelajar Auditori}

a) lebih banyak memberi pelajaran dan mengajukan pertanyaan secara lisan untuk siswa auditori, b) selama pembelajaran berlangsung, meminta siswa untuk mengulang kembali materi yang disampaikan dalam kata-katanta sendiri, c) memberi pilihan pada siswa auditori apakah akan mengambil ujian mereka secara lisan atau tertulis, d) membedakan strategi mengajar saat memberi materi, kerja kelompok, eksperimen, proyek, drama, dan lain-lain sehingga para siswa auditori tetap aman dalam elemen sosial mereka, e) memberi imbalan untuk setiap partisipasi mereka di dalam kelas, f) mengatur nada suara, infleksi, dan bahasa tubuh saat memberi materi pembelajaran di dalam kelas, g) memberi izin untuk memutar musik yang tenang di dalam kelas saat sedang berlangsung pelajaran di kelas (menggunakan headphone).

\section{Pembelajar Kinestetik}

a) memasukkannya ke kelas drama sekolah, b) memberi peluang untuk menjelajahi area luar kelas, c) mendorong untuk rajin membuat catatan, menggambar diagram, dan membuat model-model, d) berlatih soal-soal ujian sambil berjalan-jalan di taman ata sambil memainkan bola bekel, e) memasukkan anak ke sekolah yang memberi banyak pilihan pendidikan jasmani.

Dari pendapat para ahli di atas dapat disintesiskan bahwa gaya belajar adalah suatu cara khas dan unik bagaimana siswa menerima dan menyerap informasi baru yang dapat diamati saat proses belajar mengajar berlangsung. Siswa dengan gaya belajar visual belajar dengan cara melihat sehingga indera penglihatan amat berperan penting, siswa dengan gaya belajar audio belajar dengan cara mendengar sehingga indera pendengaran amat berperan penting, serta siswa dengan gaya belajar kinestetik akan lebih mudah belajar melalui aktivitas fisik dan keterlibatan langsung,

Berkaitan dengan prestasi tingkat keberhasilan belajar siswa dapat dilihat dari prestasi belajar yang diraihnya menurut Djamarah (2012:23) prestasi belajar adalah hasil yang diperoleh berupa kesan-kesan yang mengakibatkan perubahan dalam diri individu sebagai hasil dari aktivitas belajar. Pendapat tersebut diperkuat oleh Hasibuan (2018:8) yang menjelaskan bahwa prestasi belajar merupakan suatu proses kegiatan yang dilakukan oleh seseorang yang menghasilkan suatu perubahan tingkah laku yang baru sebagai hasil interaksi dengan lingkungannya. Yulianingsih dan Sobani (2017:159) menegaskan bahwa prestasi belajar siswa adalah hasil yang telah dicapai siswa selama mengikuti kegiatan belajar mengajar yang terlihat dari kecakapankecakapan siswa yang mencerminkan tingkat penguasaan materi yang telah dipahaminya. Menurut Helmawati (2018:50) faktor penentu keberhasilan (prestasi) seseorang berasal dari faktor internal dan faktor ekstermal. Faktor internal adalah faktor yang berasal dari dalam diri orang itu sendiri, seperti faktor fisiologis dan psikologis (inteligensi, sikap, bakat, minat, dan motivasi). Sementara faktor eksternal adalah faktor yang berasal dari luar dirinya, seperti faktor lingkungan sosial (kondisi rumah), sarana, dan prasarana pendukung.

Diperlukan upaya guna mencapai prestasi belajar sebagai suatu tujuan yang ingin dicapai bersama. Sulastri (2019:56) mengungkapkan upaya yang dapat dilakukan dalam meraih prestasi diantaranya tekun, berdisiplin, bekerja keras, rajin, percaya diri, tanggung jawab dan ulet, mandiri, kreatif. Mulyasa (2013:198) menjabarkan berbagai hal yang perlu diperhatikan oleh guru maupun siswa untuk melancarkan belajar dan meningkatkan prestasi belajar diantaranya hendaknya dibentuk kelompok belajar, pekerjaan 
dan latihan yang diberikan oleh guru hendaknya dikerjakan segera dan sebaik-baiknya, rajin membaca buku/majalah yang bersangkutan dengan pelajaran, berusaha melengkapi dan merawat dengan baik alat-alat belajar, selalu menjaga kesehatan agar dapat belajar dengan baik, mempersiapkan dan mengikuti ujian harus melakukan persiapan minimal seminggu sebelum ujian.

Motivasi berprestasi merupakan hal yang penting untuk mencapai suatu prestasi diantaranya prestasi belajar. Motivasi berprestasi adalah keseluruhan daya penggerak psikis di dalam diri yang dapat menimbulkan kegiatan untuk berprestasi, menjamin kelangsungan kegiatan, dan memberikan arah pada kegiatan untuk berprestasi demi tercapainya tujuan. (Lailiana dan Handayani, 2017:6). Ciriciri individu yang memiliki motivasi berprestasi tinggi menurut Scwitgebel dikutip Amir (2017:41) ditandai dengan karateristik berikut a) memiliki dorongan dalam tugas yang menuntut tanggung jawab, realistis dan menantang tujuan yang terlalu mudah dicapai atau terlalu besar resikonya, b) mencari umpan balik dari situasi pekerjaan agar dapat secala langsung menentukan hasilnya, c) individualistis dan berdaya saing untuk menggungguli orang lain, d) berupaya menangguhkan hasratnya demi masa depan yang diinginkan.

Dari pendapat para ahli dapat disintesiskan bahwa prestasi belajar adalah kecakapan yang dapat diukur berupa pengetahuan, sikap, dan keterampilan sebagai interaksi aktif antara guru dan siswa selama berlangsungnya proses belajar untuk mendapatkan hasil belajar. Terdapat dua faktor yang mempengaruhi prestasi belajar yaitu faktor internal yang berasal dari dalam diri siswa dan faktor eksternal berasal dari luar diri siswa.

\section{METODE PENELITIAN}

Jenis penelitian yang digunakan adalah jenis penelitian kualitatif dengan metode studi kasus. Melalui metode ini peneliti akan mencari dan meneliti berbagai informasi secara lengkap, detail, dan menyeluruh mengenai gaya belajar siswa berprestasi di SDN Semeru 1 Kota Bogor. Siklus prosedur penelitian secara umum terdiri dari tiga tahap yaitu tahap orientasi meliputi kegiatan observasi awal dan melakukan pendalaman masalah. Tahap eksplorasi yaitu tahap memperoleh data melalui kegiatan wawancara, observasi, dan dokumentasi. member check merupakan merupakan tahap yang dilakukan untuk mengecek kebenaran informasi yang telah dikumpulkan.

Subjek dalam penelitian ini seorang siswa kelas IV SD bernama Muhammad Rafa Setiawan. Data dalam penelitian ini merupakan semua informasi dan fakta terkait gaya belajar siswa. Data tersebut diperoleh secara berkala melalui kegiatan observasi, wawancara, dan dokumentasi. Gabungan dari ketiga teknik ini dinamakan teknik triangulasi. Penggunaan teknik triangulasi akan meningkatkan validitas kesimpulan penelitian. Sementara penentuan sumber data diambil menggunakan teknik purpose sampling yakni pemilihan sumber data atas dasar pertimbangan tertentu. Sumber data utama dalam penelitian ini yaitu siswa berprestasi, guru serta orang tua siswa sementara suber data tambahan yakni nilai rapor siswa. Data yang telah terkumpul selanjutnya dianalisis.
Analisis data dalam penelitian kualitatif dilakukan sejak sebelum memasuki lapangan, selama dilapangan, dan setelah selesai di lapangan. Menurut Miles dan Huberman (1984) ada tiga jenis kegiatan analisis data selama di lapangan yaitu reduksi data, data display, penarikan kesimpulan dan verifikasi.

\section{HASIL PENELITIAN}

Penelitian ini dilakukan sejak 16 Mei hingga 31 Julii 2020. Data dan fakta yang diperoleh peneliti berasal dari wawancara dengan pihak terkait fokus penelitian sehingga diperoleh data lengkap dan akurat, kegiatan observasi yang dilakukan selama proses penelitian, serta berbagai dokumentasi berbentuk gambar dan video saat subjek sedang belajar. Dari kegiatan observasi diperoleh fakta bahwa subjek merupakan anak yang pemalu serta kurang fasih dalam hal bercerita. Saat peneliti mengajukan pertanyaan subjek hanya menjawab dengan jawaban singkat begitu pun saat berada di sekolah subjek termasuk anak yang kurang aktif berbicara bila diminta berbicara dihadapan banyak orang subjek merasa malu, suara subjek terdengar pelan dan harus menuliskan apa yang ingin diucapkannya terlebih dulu. Semua latihan soal yang diberikan guru, dikerjakan satu persatu secara berurut dengan teliti hingga tidak ada yang terlewat. Subjek mampu menuangkan apa yang ada dipikiran ke dalam bentuk tulisan karena itu saat mengerjakan tugas mengarang subjek tidak merasa kesulitan. Subjek menyukai kegiatan membaca ketika ada tugas yang berkaitan dengan membaca suatu teks subjek lebih suka membacanya sendiri daripada dibacakan, subjek juga memiliki hobi membaca komik bertema olahraga dan superhero.

Selain melalui kegiatan observasi data diperoleh melalui kegiatan wawancara. Berdasar hasil wawancara terhadap Rafa yang dilakukan selama 3x (tiga kali) di waktu yang berbeda diperoleh informasi bahwa Berdasar hasil wawancara terhadap Rafa yang dilakukan selama 3x (tiga kali) di waktu yang berbeda diperoleh informasi bahwa situasi ribut atau berisik tidak menggangu konsentrasi subjek saat belajar. Namun situasi yang sepi/sunyi lebih disukai Rafa agar dapat berkonsentrasi dengan lebih baik dalam belajar. saat sedang belajar subjek terlihat tenang dan tidak banyak melakukan aktivitas fisik misalnya berjalan kesana kemari atau pindah dari satu tempat ke tempat lainnya. Hal ini diperkuat dengan hasil wawancara guru kelas dan orang tua subjek. Subjek selalu mencatat apa yang ditulis guru di papan tulis dengan tulisan yang rapi agar mudah dibaca kembali saat sedang belajar di rumah hal ini diperkuat dengan hasil wawancara terhadap subjek pada 6,9 dan 13 Juni serta didukung dengan wawancara terhadap guru yaitu Ibu Ety Sudiarti, S.Pd yang dilaksanakan pada 16 Mei, 2 Juni dan 18 Juni 2020 yang menyatakan bahwa rafa mencatat lengkap semua materi yang telah guru berikan. Hal ini pun dikonfirmasi kembali oleh orang tua Rafa yaitu Ibu Yeti yang diwawancarai pada 8,9 dan 13 Juni 2020. Dalam wawancara tersebut Ibu Yeti menjawab dengan konsisten bahwa Rafa selalu mencatat materi yang diberikan oleh gurunya di sekolah.

Subjek lebih cepat mengingat materi yang sedang dipelajari dengan cara membaca dibandingkan mendengarkan. 
Berdasar hasil wawancara yang dilakukan terhadap subjek, guru kelas dan orang tua terdapat jawaban yang bervariasi. Pada wawancara yang dilakukan dengan rafa pada 6,9 dan 13 Juni Rafa megungkapkan bahwa mendengar dan membaca sama saja baginya namun ia lebih cenderung mudah mengingat jika membaca sendiri. Sedangkan wawancara bersama Ibu Ety pada 16 Mei, 2 Juni dan 18 Juni didapat informasi bahwa Rafa lebih suka mendengar. Hal ini didasari oleh asumsi Bu Ety bahwa anak-anak lebih suka mendengar kemudian berargumen sendiri dari apa yang sudah ia dengar. Sementara itu wawancara yang dilakukan pada 8.9 dan 13 Juni terhadap Ibu Yeti selaku Ibunda Rafa menjelaskan bahwa Rafa lebih mudah ingat jika membaca sendiri dan mendengarkan penjelasan.

Cara mengajar guru yang subjek sukai yaitu guru tidak hanya menjelaskan materi pelajaran secara lisan saja namun guru juga menuliskan apa yang dijelaskan serta memberi contoh-contohnya. Adapun penampilan subjek saat berada di sekolah selalu terlihat bersih dan rapi karena subjek merupakan siswa yang mementingkan penampilannya hal ini sesuai dengan hasil wawancara yang dilakukan pada subjek, guru di kelas yaitu Ibu Eti dan orang tua di rumah yaitu Ibu Yeti. Berdasar hasil wawancara subjek yang dilakukan pada 6, 9 dan 132020 Juni diperoleh informasi bahwa subjek akan berusaha untuk bertanya kepada guru atau orang tua jika mengalami kesulitan dalam belajar terkadang Rafa pun tampak berdiskusi dengan temannya. Hal ini diperkuat juga oleh hasil wawancara dengan guru kelas yaitu Bu Eti pada 16 Mei, 2 Juni dan 18 Juni 2020. Sedangkan berdasar hasil wawancara bersama orang tua Rafa yaitu Ibu Yeti yang dilakukan pada 8,9 dan 13 Juni 2020 diperoleh informasi, bahwa Rafa akan bertanya kepada orang tua jika terdapat kesulitan memahami suatu materi di sekolah agar dijelaskan kembali oleh ayah ataupun ibunya.

Sekolah menyediakan berbagai fasilitas untuk mendukung kegiatan belajar siswa hal ini berdasar hasil wawancara dengan Rafa yang dilaksanakan pada 6, 9 dan 13 Juni 2020 bahwa Rafa dan tiap anak di sekolah mendapat fasilitas buku paket yang dapat dipinjam gratis dan dibawa pulang agar siswa dapat belajar kapanpun dan dimanapun. Bu Ety selaku guru kelas yang diwawancarai pada 16 Mei, 2 Juni dan 18 Juni 2020 pun menambahkan bahwa fasilitas yang disediakan sekolah untuk mendukung kegiatan belajar siswa sudah cukup lengkap, meliputi sarana dan prasarana, buku siswa, buku perpustakaan, serta alat-alat peraga yang disediakan di sekolah. Sedangkan wawancara bersama orang tua Rafa yaitu Ibundanya, Ibu Yeti yang dilaksanakan pada 8,9 dan 13 Juni 2020 menyatakan bahwa sekolah memfasilitasi setiap siswa dengan buku paket yang dipinjamkan dan dapat dibawa ke rumah untuk memfasilitasi siswa dalam belajar selain di sekolah.

Wawancara terakhir yang dilakukan adalah menggali informasi kepada semua pihak yang diwawancara baik Rafa, $\mathrm{Bu}$ ety sebagai guru kelasnya maupun Ibundanya $\mathrm{Bu}$ Yeti berdasarkan sudut pandang mereka masing-masing tentang bagaimana cara mempertahankan dan meningkatkan prestasi yang telah dimiliki Rafa. Berdasarakan hasil wawancara dengan Rafa pada 6, 9 dan 13 Juni 2020 diperoleh informasi bahwa cara Rafa untuk tetap mempertahankan prestasinya adalah dengan belajar secara konsisten. Ia belajar tiap hari dan waktu terbaik yang dipilihnya adalah malam hari. Sedangkan berdasar hasil wawancara dengan guru kelas yaitu Ibu Ety Sudiarti, S.Pd yang dilaksanakan pada 16 Mei, 2 Juni dan 18 Juni 2020 diperoleh informasi bahwa cara yang dilakukan Bu Ety agar Rafa dapat mempertahankan dan meningkatkan prestasinya adalah dengan cara selalu mengingatkan dan memberi motivasi selayaknya falsafah Tut Wuri Handayani yang diembannya bahwa sebagai guru ia harus mendorong siswanya dari belakang untuk tetap berprestasi. Selain itu bu Ety juga selalu memberi masukan, teguran dan nasihat agar Rafa tetap semangat mempertahankan bahkan meningkatkan prestasinya. Sedangkan berdasar hasil wawancara yang dilakukan terhadap orang tua rafa yaitu ibunya, Ibu Yeti pada 8,9 dan 13 Juni 2020 diperoleh informasi bahwa cara sang ibu agar anaknya tetap mempertahankan dan meningkatkan prestasinya adalah dengan selalu mengingatkannya untuk selalu belajar, mengajak dan menemani Rafa belajar setiap malam.

\section{PEMBAHASAN}

Subjek penelitian sebenarnya memiliki ketiga gaya belajar meliputi gaya belajar visual, audio, dan kinestetik dari ketiga gaya tersebut dapat disimpulkan bahwa subjek memiliki kecenderungan gaya belajar visual. Kesimpulan tersebut didasarkan atas temuan-temuan yang didapat saat peneliti melakukan penelitian mulai tanggal 16 Mei hingga 31 Juli 2020. Gaya belajar visual memilik karakteristik tersendiri seperti yang diungkapkan Suyono dan Hariyanto (2013:151) antara lain a) lebih mudah mengigat apa yang dilihat daripada yang didengar, b)mudah mengingat dengan asosiasi visual, c) pembaca yang cepat dan teku, memiliki hobi membaca, d) lebih suka membaca sendiri daripada dibacakan, e) biasa berbicara dengan cepat, karena dia tidak merasa perlu mendengarkan esensi pembicaraannya, f) mempunyai masalah untuk merngingat instruksi verbal, kecuali jika dituliskan, dan sering minta bantuan orang lain untuk mengulangi intruksi verbal tersebut, g) sering lupa menyampaikan pesan verbal kepada orang lain, h) pengeja yang baik, kata demi kata, i) sering menjawab pertanyaan dengan jawaban singkat, ya atau tidak, sudah atau belum, j) mempunyai kebiasaan rapi dan teratur, karena itu yang akan dilihat orang, k) mementingkan penampilan, baik dalam hal pakaian maupun presentasi, 1) memiliki kemampuan dalam perencanaan dan pengaturan jangkan panjang yang baik, m) teliti terhadap rincian, hal-hal kecil yang harus dilakukan, n) biasanya tidak terganggu oleh suara ribut, o) Lebih suka melakukan demonstrasi daripada berpidato, p) membutuhkan pandangan dan tujuan yang menyeluruh dan bersikap waspada sebelum secara mental merasa pasti tenang suatu masalah atau proyek, terbiasa melakukan check and recheck sebelum membuat simpulan, q) lebih menyukai seni visual daripada seni musik, r) suka mencorat coret tanpa arti sebelum berbicara di telepon atau pada saat melakukan rapat.

Kecenderungan gaya belajar visual yang dimiliki subjek berdasar poin-poin di atas diantaranya terlihat dari perilaku sehari hari subjek seperti mementingkan kerapihan 
baik kerapihan berpakaian maupun tulisan (memenuhi poin J). Pada poin $\mathrm{C}$ dan $\mathrm{D}$ yaitu tentang hobi dalam membaca yang dimiliki oleh siswa dengan karakter gaya belajar visual dimiliki oleh Rafa yang lebih suka membaca sendiri daripada dibacakan. Subjek lebih cepat mengingat materi yang sedang dipelajari dengan cara membaca dibandingkan mendengarkan. Pada poin (n) disebutkan karakteristik pembelajar visual biasanya tidak terganggu oleh suara ribut. Hal ini juga sesuai dengan karakteristik Rafa meski terdengar suara TV atau keributan Rafa tetap mampu berkonsentrasi. Poin selanjutnya adalah poin $\mathrm{r}$ yang menyatakan karakter pembelajar visual diantaranya yaitu, suka mencorat coret tanpa arti hal ini sesuai dengan subjek dimana subjek agak kesulitan bila harus berbicara dihadapan banyak orang. Hal lain yang menunjukkan bahwa subjek memiliki kecenderungan gaya belajar visual yaitu subjek akan lebih mudah mengingat materi yang sedang dipelajari bila melihat dan mencatat apa yang ditulis guru di papan tulis. Adapun prestasi yang diraih subjek didukung oleh faktor dari dalam diri subjek sendiri seperti belajar dan mengerjakan PR tanpa harus dipaksa, pantang menyerah dengan selalu bertanya pada bila ada materi yang belum dipahami, serta serta memiliki motivasi belajar yang tinggi sedangkan faktor dari luar diri subjek seperti perhatian dari orang tua dimana orang tua subjek selalu memantau kegiatan belajar anaknya, motivasi yang diberikan guru, serta tersedianya sarana dan prasarana memadai sesuai dengan apa yang diungkapkan Helmawati (2018:35) bahwa Faktor penentu keberhasilan (prestasi) seseorang berasal dari faktor internal dan faktor ekstermal.

\section{SIMPULAN}

Berdasarkan pembahasan hasil penelitian dan temuan data yang telah diuraikan sebelumnya maka dapat diambil kesimpulan sebagai berikut :

Gaya belajar dominan yang dimiliki subjek penelitian yaitu gaya belajar visual karena Rafa akan lebih mudah mengingat informasi baru yang diperoleh bila dapat melihatnya secara langsung misalnya dengan melihat apa yang ditulis guru di papan tulis ketika sedang menjelaskan ataupun dengan membaca. Dari segi penampilan Rafa selalu memperhatikan kerapihan berpakaian. Meskipun suasana sedang dalam kondisi berisik Rafa tetap dapat fokus dan berkonsentrasi mendengarkan guru dan mengerjakan tugas. Sifat pemalu yang dimiliki Rafa membuatnya kurang menyukai kegiatan belajar yang mengaharuskannya tampil berbicara dihadapan banyak orang. Bila diminta menjelaskan sesuatu Rafa akan menjawabnya dengan singkat. Perilaku lain yang ditunjukkan Rafa yaitu dapat duduk tenang tampa merasa gelisah dalam waktu lama saat sedang belajar.

Prestasi yang diraih Rafa saat ini dikarenakan usaha serta minat dan motivasi belajar yang tinggi. Selain itu dukungan dari orang tua dan guru serta lingkungan sekolah juga sangat mempengaruhi prestasi Rafa. orang tua Rafa selalu mengingatkan untuk terus belajar adapun guru selalu memotivasi, membimbing, dan membantu Rafa bila ada materi yang tidak dipahami sehingga Rafa selalu memiliki prestasi belajar yang tinggi. Berbagai kegiatan ekstrakurikuler yang diselenggarakan sekolah membuat Rafa mampu mengembangkat bakatnya dalam olahraga futsal sehingga mampu berprestasi dalam bidang tersebut.

\section{REFERENSI}

Amir, M.A.A. 2017. Meningkatkan Motivasi Berprestasi Peserta didik. Surabaya : CV Garuda Mas Sejahtera.

Djamarah, Syaiful Bahri. 2012. Prestasi Belajar dan Kompetensi Guru. Surabaya : Usaha Nasional.

Hasibuan, Abdul Aziz. 2018. "Kontribusi Lingkungan Belajar dan Proses Pembelajaran Terhadap Prestasi Belajar Siswa di Sekolah". Jurnal Tarbiyah. vol 25(2), h.1-22.

Helmawati. 2018. Mendidik Anak Berprestasi Melalui 10 Kecerdasan. Jakarta. Remaja Rosdakarya.

Hidayat, Syarif. 2012. Profesi Kependidikan. Tangerang: PT Pustaka Mandiri.

Lailiana, Nur Aulia. 2017. "Motivasi Berprestasi Ditinjau dari Komiten Terhadap Tugas Pada Mahasiswa". Jurnal Unissula. Vol 1(1), h.1-8.

Mulyasa. 2013. Pengembangan dan Implementasi Kurikulum 2013. Bandung: PT Remaja Rosdakarya Offset.

Priansa, Donni Juni. 2017. Pengembangan Strategi \& Model Pembelajaran. Bandung : CV Pustaka Setia.

Priyatna, Andi. 2013. Pahami Gaya Belajar Anak. Jakarta : PT Elex Media Komputindo Kelompok Gramedia.

Subini, Nini. 2013. Rahasi Gaya Belajar Orang Besar. Yogyakarta : PT Buku Kita.

Sulastri, Siti. 2019. Berakhlak Mulia Raih Prestasi. Jakarta. Mutiara Aksara.

Suyono dan Hariyanto. 2013. Belajar dan Pembelajaran. Bandung : PT Remaja Rosdakarya.

Ula, Shimatul S. 2013. Revolusi Belajar. Depok : Ar-Russ Media.

Yuianingsih, Lia Tresna dan A.Sobandi. 2017. "Kinerja Mengajar Guru Sebagai Faktor Determinan Prestasi Belajar Siswa". vol 2(2), h. 1-9. 